\title{
Johannine research in Africa, part 2: An annotated bibliography
}

\begin{abstract}
Author:
Jan G. van der Watt ${ }^{1,2}$

Affiliations:

${ }^{1}$ Source Texts of Judaism and Christianity, Radboud University, Nijmegen, the Netherlands

${ }^{2}$ Department of New Testament, Faculty of Theology, University of the Free State, South Africa

Correspondence to: Jan van der Watt

Email:

j.vanderwatt@ftr.ru.nl

Postal address:

Paterserf 07, Molenhoek

6584 GA, the Netherlands

Dates:

Received: 15 Jan. 2015

Accepted: 22 May 2015

Published: 24 July 2015

How to cite this article: Van der Watt, J.G., 2015, 'Johannine research in Africa, part 2: An annotated bibliography', In die Skriflig 49(2), Art. \#1929, 15 pages. http://dx.doi.org/10.4102/ ids.v49i2.1929

\section{Note:}

This article is dedicated to Jan du Rand, a friend and colleague, for his significant contribution to New Testament and specifically Johannine studies.

\section{Copyright:}

(C) 2015. The Authors. Licensee: AOSIS OpenJournals. This work is licensed under the Creative Commons Attribution License.
\end{abstract}

\section{Read online:}

No annotated bibliography on the research on Johannine literature in Africa exists. This means that no proper overview of Johannine research in Africa is available. This article (as part 2 of a broader analysis) fills that lacunae by presenting a comprehensive bibliography of research done on John in Africa (combined with a proper analysis in part 1). It classifies the available research according to major topics and presents the publications in chronological order under each topic.

Johannese navorsing in Afrika, deel 2: 'n Geannoteerde bibliografie. Daar bestaan geen geannoteerde bibliografie van die Johanneïese navorsing in Afrika nie. wat beteken dat Johannese navorsers geen behoorlike oorsig met betrekking tot bestaande navorsing het nie. Hierdie artikel (as die tweede aflewering van 'n meer omvattende analise) wil daardie leemte vul deur 'n omvattende bibliografie van die Johannese navorsing in Afrika aan te bied (gekombineer met 'n deeglike analise in deel 1). Die navorsing word volgens hooftemas geklassifiseer en chronologies onder elke tema aangebied.

\section{Introduction}

This annotated bibliography forms the second part of the research regarding results on Johannine research in Africa. The first part is an analytical survey of the research. ${ }^{1}$ This survey of the current publications in the field of Johannine studies in Africa is an effort to 'take stock' of the research activities in this field. This is imperative for future research and responsible research planning in this field.

The information presented here is not readily available and this is the only comprehensive list of available research on John in Africa, making it a key research tool. The aim of the annotations is to determine where Johannine scholars stand, what their strengths and weaknesses are, and what still needs to be done in this field. The importance of this information for research is that it serves as an indication for Johannine researchers of what was already done (so that the wheel does not have to be rediscovered again), and what should be addressed in future to strengthen Johannine research in Africa. In order to 'plot' the development of themes and interests in the research it was decided to follow a chronological rather than an alphabetical listing of the articles. Obviously there are also a large number of 'popular publications' on John. These are not covered in this bibliography, neither are PhD dissertations, except if they are published as books.

The advantage of such classification is that it offers a comprehensive overview of the foci of Johannine research in Africa. The lacunae become evident and challenge researchers to address the areas that still lack attention. Obviously, every form of classification has its problems. Some articles deal with more than one theme, in which case the same article is classified under different categories. In many cases the arguments within a particular article deal with several topics the question is whether (and when) one should mention the particular article under all the categories it touches upon. It was decided against such a detailed classification, since the aim of this annotated bibliography is rather to plot the major areas of Johannine research in Africa. Classification is therefore restricted to the major themes addressed by the respective articles.

\section{Publications with Johannine Christology as a central theme}

Christology forms the heart of Johannine theology. The centrality of the Johannine Christology is also evident in African Johannine research. The range of topics and themes that are addressed 
varies, focusing both on general Christological themes as well as articles focusing on specific aspects of Christology that form part of the African 'oeuvre'. This is one of the more fruitful areas of African Johannine research.

Bidzoga, G.R., 2006, 'Jesus, the way to the Father in John 14:1-14: A link with the African situation today', Hekima Review 35, 33-45.

Botha, J.E., 1991, Jesus and the Samaritan woman: A speech act reading of John 4:1-42, Brill, Leiden.

Du Rand, J.A., 1980, 'Nuwere perspektiewe in die studie van die Christologie van die Evangelie volgens Johannes', in A.B. $\mathrm{du}$ Toit (red.), Die Nuwe-Testamentiese wetenskap vandag, pp. 78-118, Universiteit van Pretoria, Pretoria.

Du Rand, J.A., 1985, 'The characterisation of Jesus as depicted in the fourth Gospel', Neotestamentica 19, 18-36.

Du Rand, J.A., 2002, ‘Die Johannese Logos kom opnuut tuis in Afrika', Verbum et Ecclesia 23(1), 80-91.

Du Rand, J.A., 2002, 'The Johannine Jesus in Africa?', in F. Segovia, A. Culpepper \& J. Painter (eds.), Word, theology, and community in John, pp. 211-228, Fortress, Philadelphia.

Folarin, G.O., 2002, 'Functional Christology in the fourth Gospel: Implications for African Christianity', African Journal of Biblical Studies 18(2), 22-38.

Gitari, D., 1996, 'The good shepherd: Ezekiel 34, John 10 and Psalm 23', in D. Gitari \& K. Bediako (eds.), In season and out of season: Sermons to a nation, pp. 128-130, Regnum, Carlisle.

Lioy, D., 2007, 'Jesus as Torah in John 2:1-22', Conspectus 4, 23-39.

Manus, C.U., 1991, 'Jesus and the Jewish authorities in the fourth Gospel', in W. Amewowo, P. Arowele \& B. Balembo (eds.), Johannine communities, pp. 135-155, Catholic Faculty of Kinshasa, Kinshasa.

Manus, C.U., 2002, ‘Reconstructing Christology for Africa of the 21st century: A re-reading of Mark 11:15-19 and parallels: Matt. 21:12-17; Lk. 19:45-48; John 2:13-22', African Journal of Biblical Studies 18(2), 1-21.

Mbachu, H., 1996, Cana and Calvary revisited in the fourth Gospel narrative: Mario-Christology in context, Hansel-Hohenhausen, Frankfurt.

Nortjé, S.J., 1996, 'Lamb of God (John 1:29): An explanation from ancient Christian art', Neotestamentica 30(1), 141-150.

Nwigure, N.S., 2003, 'Johannine Christology: A critical analysis', in S.O. Abogunrin \& J.O. Akao (eds.), Christology in African context, pp. 195-203, Nigerian Association of Biblical Studies, Ibadan.
Obielosi, D.C., 2008, Servant of God in John, Peter Lang, Frankfurt am M.

Oguike, D.C.A., 2003, 'Johannine Christology', in S.O. Abogunrin \& J.O. Akao (eds.), Christology in African context, pp. 192-205, Nigerian Association of Biblical Studies, Ibadan.

Owan, K.J.N., 1996, 'Jesus, justice and John 10:10: Liberation hermeneutics in the Nigerian context', Nigerian Journal of Theology 10(1), 18-42.

Sindima, H.J., 1990, 'Moyo: Fullness of life - A hermeneutic of the Logos in John's Prologue', African Christian Studies 6(4), $50-62$.

Suggit, J., 1999, 'Jesus the gardener: The atonement in the fourth Gospel as re-creation', Neotestamentica 33, 161-168.

Van Aarde, A.G. \& Ingram, R., 2005, 'Van Plato tot Augustinus: Die vroeë Wirkungsgeschichte van die Logosmotief in Johannes', Ekklesiastikos Pharos 87, 235-258.

Van der Watt, J.G., 1993, 'Jesus, God of Mens!? 1 Joh 1:1-4 eksegeties oorweeg', Nederduitse Gereformeerde Teologiese Tydskrif 34(3), 275-292.

Van der Watt, J.G., 2002, 'The presence of Jesus through the Gospel of John', Neotestamentica 36(1-2), 89-95.

Van der Watt, J.G., 2007, 'I am the bread of life: Imagery in John 6:32-51', Acta Theologica 27(2), 186-204.

Van der Watt, J.G., 2007, 'The father shows the son everything: The imagery of education in John 5,19-23', Acta Patristica et Byzantina 18, 263-276.

Van der Watt, J.G., 2009, 'Waarheid in die Evangelie van Johannes', Acta Patristica et Byzantina 20, 159-178.

\section{Publications predominantly dealing with pneumatology in John}

Without a clear understanding of how spirits and powers work within a holistic worldview, African Christianity cannot be understood. Survival in this world implies proper control and manipulation of the influence of spirits on one's personal and social life. It is therefore surprising that so little African research is available on the Spirit in John. The majority of research is done by southern (white) scholars. African Johannine scholars across the continent need to pay more attention to this aspect of the Johannine material if they want to explore the impact the text could have on African Christianity in any significant depth. In particular, the imagery of the Paraclete that concretises the presence of Jesus amongst the Johannine Christians should not be overlooked.

Botha, J.E. \& Tuppurainen, R., 2008, 'The roles of the Spirit in John 16:4b-15: An integrated reading', Acta Patristica et Byzantina 19, 23-43. 
Draper, J.A., 1992, 'The soteriological function of the Spirit/ Paraclete in the farewell discourses in the fourth Gospel', Neotestamentica 26(1), 13-29.

Joubert, J., 2007, 'Johannine metaphors/symbols linked to the Paraclete-Spirit and its theological implications', Acta Theologica 27(1), 83-104.

Osunwoke, C.I., 2006, 'The Holy Spirit and the 21st century church', Journal of New Testament Research 1, 92-112.

Rwehumbiza, R.K.P., 1991, 'Presence and activity of the Holy Spirit in Johannine community', in W. Amewowo, P. Arowele \& B. Balembo (eds.), Johannine communities, pp. 202-241, Catholic Faculty of Kinshasa, Kinshasa.

Van der Watt, J.G., 2000, “The Spirit gives life": Reading 1 John in African context', Protokolle zur Bibel 9(1), 1-22.

\section{Publications focusing on salvation (soteriology) in John}

Christology and soteriology overlap in John - Jesus is the one who brings life to those who are dead and light to those who are in the darkness. Since this is a significant characteristic of the Gospel it is to be expected that this topic will receive due attention. This is obviously a wide theme in John and the variety of topics vouch for this, such as life, birth, faith, atonement, the cross-events, et cetera are also addressed in African Johannine research.

Adamo, D.T., 1989, Sin in John's Gospel, ERT 13(3), 216-227.

Adamo, D.T., 1990, 'Jesus' resurrection and his disciple's acceptance: An exegetical study of John chapter 20', Deletion Biblikos Meleton 19(2), 13-21.

Ahoua, R., 2008, The transference of the three mediating institutions of salvation from Caiaphas to Jesus: A study of Jn 11:45-54 in the light of the Akan myth crossing the river, Peter Lang, Bern.

Draper, J.A., 1992, 'The soteriological function of the Spirit/ Paraclete in the farewell discourses in the fourth Gospel', Neotestamentica 26(1), 13-29.

Dube, M.W., 1996, Saviour of the world but not of this world: A post-colonial reading of spatial construction in John, Scholars, Atlanta.

Du Preez, J., 1975, “'Sperma tou Theou” in 1 Joh 3:9', Neotestamentica 9, 105-110.

Du Rand, J.A., 1988, ‘Die betekenis van Martha se belydenis volgens die vertelling van Johannes 11:27', Fax Theologica 8(2), 30-39.

Du Toit, A.B., 1990, 'Sondebelydenis volgens 1 Johannes', Nederduitse Gereformeerde Teologiese Tydskrif 31(4), 520-525.
Du Toit, A., 1991, 'The aspect of faith in the Gospel of John with special reference to the farewell discourses of Jesus', Neotestamentica 25(2), 327-340.

Kok, J., 2009, ‘Die opstanding van Jesus as kulminerende genesingshandeling in Johannes', Verbum et Ecclesia 30(1), 112-147.

Kok, J., 2011, 'The chaos of the cross as fractal of life: The birth of the post resurrection, missional dimension in John', Neotestamentica 45(1), 130-145.

Monsengwo, P.L., 1991, 'La foi dans les Ecrits johanniques', in W. Amewowo, P. Arowele \& B. Balembo (eds.), Johannine communities, pp. 10-27, Catholic Faculty of Kinshasa, Kinshasa.

Ndayango, A.C.C., 2001, Wunder, Glaube, und Leben bei Johannes: Eine exegetisch-hermeneutische Studie am Beispiel von Joh 3 im Hinblick auf die Inkulturationsaufgabe, Norbert, Bonn.

Suggit, J., 1999, 'Jesus the gardener: The atonement in the fourth Gospel as re-creation', Neotestamentica 33(1), 161-168.

Umorem, A., 1993, Being born again: An interpretation of Jn. 3:3, in relation to Christian religious experiences, Catholic Theological Association of Nigeria, Lagos.

Van der Watt, J.G., 1985, 'A new look at John 5:25-29 in the light of the use of the term "eternal life" in the Gospel according to John', Neotestamentica 19, 71-86.

Van der Watt, J.G., 1987, 'Eternal life in John's Gospel: A denotative investigation', Nederduitse Gereformeerde Teologiese Tydskrif 28(4), 255-262.

Van der Watt, J.G., 1995, "Daar is die Lam van God ...": Versoenende offertradisies in die Evangelie volgens Johannes', Skrif en Kerk 16(1), 142-158.

Van der Watt, J.G., 2002, 'Verheerliking en die kruis? Die Johannese herinterpretatsie van die kruis as glorie (doxa)', Nederduitse Gereformeerde Teologiese Tydskrif 43(3/4), 606-615.

Van der Watt, J.G., 2003, 'The cross/resurrection-events in the Gospel of John with special emphasis on the confession of Thomas (20:28)', Neotestamentica 37(1), 127-145.

Van der Watt, J.G., 2003, 'Waar is God werklik? Redding in die Evangelie volgens Johannes', Nederduitse Gereformeerde Teologiese Tydskrif 44(3/4), 586-577.

Van der Watt, J.G., 2004, 'Hoe akkuraat kan 'n Bybelvertaling wees? Geboorte (gennā̄) in 1 Johannes 5:1-4 as voorbeeld', Hervormde Teologiese Tydskrif 60(3), 1-22.

Van der Watt, J.G., 2005, 'Salvation in the Gospel according to John', in J.G. van der Watt (ed.), Salvation in the New Testament: Perspectives on soteriology, pp. 101-131, Brill, Leiden. 
Van der Watt, J.G., 2012, 'Redding in die Evangelie volgens Johannes', Nederduitse Gereformeerde Teologiese Tydskrif 53(1/2), 158-178, electronically available: http://ngtt. journals.ac.za/pub/issue/view/6/showToc

\section{Publications on ecclesiology in African Johannine research}

Although several articles deal with ecclesiological issues in Johannine literature, there is no clear unity of interest. The articles cover a variety of texts and themes. The church in Africa was, and is, discovering and establishing its ecclesiological nature over the last couple of decades. Therefore it is a pity that the Johannine ecclesiology with its strong focus on community, fellowship, sharing and unity is not explored in more detail, since these are all aspects that are importance to African life. John could offer many valuable insights to the African Christian communities. Research in this area is dearly needed.

Arowelle, P.J., 1991, 'The scattered children of God (John 11:52): A Johannine ecclesial cliché', in W. Amewowo, P. Arowele \& B. Balembo (eds.), Johannine communities, pp. 181-201, Catholic Faculty of Kinshasa, Kinshasa.

Diouf, J.-N., 1999, ‘La nouvelle renaissance dans le Prologue de Saint Jean (Jn 1,11-13)', in J.-B. Matand Bulembat, P.D. Njoroge, L. Mhagama \& P. Zoungrana (eds.), The church as family and biblical perspectives, pp. 99-112, Catholic Faculty of Kinshasa, Kinshasa.

Du Rand, J.A., 1986, 'Johannes 17: Jesus se gebed om eenheid en solidariteit te midde van krisis en konflik', in J.C. Breytenbach (red.), Eenheid en konflik, pp. 105-133, NG Kerkboekhandel, Pretoria.

Du Rand, J.A., 1992, 'A story and a community: Reading the first farewell discourse (John 13:31-14:31) from narratological and sociological perspectives', Neotestamentica 26(1), 31-45.

Draper, J.A., 1991, 'The Johannine community and its implications for a democratic Society', in K. Nurnberger (ed.), A democratic vision for South Africa, pp. 115-136, Encounter Publications, Pietermaritzburg.

Draper, J.A., 1997, 'Temple, tabernacle and mystical experience in John', Neotestamentica 31(2), 263-288.

Draper, J.A., 2000, 'Holy seed and the return of the diaspora in John 12:24', Neotestamentica 34(2), 347-359.

Lombard, H.A., 1998, 'Orthodoxy and other-worldliness of the church: Johannine perspectives on Christianity in a new South Africa', Neotestamentica 32(2), 497-508.

Moruthane, S.W. \& Nortje-Meyer, L., 2008, 'Family imagery in John', Ekklesiastikos Pharos 90, 81-97.
Olivier, W.H. \& Van Aarde, A.G., 1991, 'The community of faith as a dwelling-place of the Father: "Basileia tou Theou" as "household of God" in the Johannine farewell discourse', Neotestamentica 25(2), 379-400.

Smit, G., 2011, 'Witness in John 1-4: Towards an emerging, missiological church', Verbum et Ecclesia 32(1), 7. doi: 10.4102/ ve.v32i1.389

Snodderly, B. \& Van der Merwe, D.G., 2007, 'Status regeneration in first John: Social scientific and literary perspectives', Acta Patristica et Byzantina 18, 179-213.

Umoh, C., 2005, 'Authority, crisis and conflict in the Johannine community: An inculturation hermeneutic of 1 John', Journal of Inculturation Theology 7(1), 15-30.

Van der Merwe, D.G., 2002, 'The character of "unity" expected among the disciples of Jesus according to John 17:20-23', Acta Patristica et Byzantina 13, 222-252.

\section{Johannine eschatology in African research}

Eschatology as a specific theme has played a minimal role in African Johannine studies up to this point, except for two articles that were published as the result of a conference held in Pretoria on the eschatology of the New Testament. There are, however, some articles that deal with issues that could be described as expressions of realised eschatology, but the aim of these articles is not to deal with eschatology as such.

Maritz, P., 2007, 'Some time in John: Tensions between the hour and eternity in John 17', Neotestamentica 41(1), 112-130.

Van der Merwe, D.G., 2002, 'Hōra, a possible theological setting for understanding Johannine eschatology', Acta Patristica et Byzantina 13, 253-285.

Van der Watt, J.G., 2011, 'Eschatology in the Gospel according to John', in J.G. van der Watt (ed.), Eschatology of the New Testament and some related documents, pp. 109-140, Mohr Siebeck, Tübingen

\section{Publications on the ethics of John}

Over the last three decades there was an evergreen interest in the ethics of John, mainly in the South. Some of the leading work on the ethics of John was done by Africans, who were also largely responsible for the current revival of interest in Johannine ethics. The publications range from general articles that explore the ethical structure of John, to publications on detailed ethical issues.

Botha, J.E. \& Rousseau, P.A., 2005, 'For God did not love the whole world - only Israel! John 3:16 revisited', HTS Hervormde Teologiese Studies 61(4), 1149-1168. 
Draper, J.A., 1999, “"My Father is working until now and I am working" (John 5:17): Reflections on a theology of work and rest', Bulletin for Contextual Theology 6(3), 43-47.

Du Rand, J.A., 1980, “'In waarheid en liefde ...": 'n Metodologiese sleutel tot die verstaan van die tweede Johannesbrief', Humanitas 5(4), 317-326.

Du Rand, J.A., 1982, Entole in die Johannesevangelie en -briewe, Nuwe-Testamentiese Werkgemeenskap in Suid-Afrika, Pretoria.

Du Rand, J.A., 1989, 'Johanneïese identifikasie - Etiese momente in die Johannesbriewe', Nederduitse Gereformeerde Teologiese Tydskrif 30(2), 29-47.

Du Rand, J.A., 1990, “"Verstaan julle wat Ek vir julle gedoen het?" (Joh 13:12): Die voetewassing as Johannese hupodeigma', in L. Nortje (red.),' Hupodeigma - 'n Vriend in ons poorte: Feesbundel vir PJ du Plessis, pp. 61-74, Randse Afrikaanse Universiteit, Johannesburg.

Le Roux, E., 2010, 'n Johannese perspektief op die huwelik, geslagsrolle en seksualiteit in 'n postmoderne samelewing', Verbum et Ecclesia 31(1), 8 pages online. doi: 10.4102/ ve.v31i1.347.

Makambu, A., 2009, “'Les pauvres, vous les aurez toujours avec vous" (Jn 12,8): Amour de Jésus versus service des pauvres?', in P. Bere, A. Kabasele, M.S. Nwachukwu \& A. Umoren (eds.), Poverty and riches in the Bible, pp. 213-237, Panafrican Association of Catholic Exegetes, Kinshasa.

Omotoye, R., 2006, 'Jesus Christ and the adulterous woman: A case for embracing HIV / AIDS patients in Nigeria', in S.O. Aborgunrin \& J.O. Akao (eds.), Biblical view of sex and sexuality from African perspective, pp. 300-308, Nigerian Association of Biblical Studies, Ibadan.

Ras, J.M.J., 2010, 'Jesus, moral regeneration and crime in the Gospel of John', Inkanyiso 2(2), 115-121.

Schaeffler, E., 2006, 'Jesus' non-violence at his arrest: The synoptics and John's Gospel Compared', Acta Patristica et Byzantina 17, 312-326.

Van der Merwe, D.G., 2001, 'Imitatio Christi in the fourth Gospel', Verbum et Ecclesia 22(1), 131-148.

Van der Watt, J.G., 1988, 'Broederliefde in 1 Johannes', in J.C. Breytenbach (red.), Kerk en konteks, pp. 65-76, NG KerkUitgewers, Pretoria.

Van der Watt, J.G., 1993, 'Julle moet mekaar liefhê: Etiek in die Evangelie volgens Johannes', Scriptura (S9a), 74-96.

Van der Watt, J.G., 1997, 'Liefde in die familie van God', Hervormde Teologiese Studies 53(3), 543-556.
Van der Watt, J.G., 1999, 'Ethics in 1 John: A literary and socioscientific perspective', Catholic Biblical Quarterly 61(4), 491-511.

Van der Watt, J.G., 2006, 'Ethics alive in imagery', in J. Frey, J.G. van der Watt \& R. Zimmermann (eds.), Imagery in the Gospel according to John/Bildersprache im Johannesevangelium, pp. 421-448, Mohr Siebeck, Tübingen.

Van der Watt, J.G., 2006, 'Ethics and ethos in the Gospel according to John', Zeitschrift für die Neutestamentliche Wissenschaft 97(2), 147-176.

Van der Watt, J.G., 2006, 'Radical social redefinition and radical love: Ethics and ethos in the Gospel according to John', in J.G. van der Watt (ed.), Identity, ethics, and ethos in the New Testament, pp. 107-137, De Gruyter, Berlin.

Van der Watt, J.G., 2009, 'The good and the truth in John', in E. Poplutz (ed.), Studien zu Matthäus und Johannes/Études sur Matthieu et Jean, Festschrift für Jean Zumstein, pp. 317-333, Theologische Verlag Zürich, Zürich.

Van der Watt, J.G., 2009, 'Waarheid in die Evangelie van Johannes', Acta Patristica et Byzantina 20, 159-178.

Van der Watt, J.G., 2010, 'Ethics through the power of language: Some exploration in the Gospel according to John', in J.G. van der Watt \& R. Zimmermann (eds.), Moral language in the New Testament, pp. 139-167, Mohr Siebeck, Tübingen.

Van der Watt, J.G., 2011, 'The Gospel of John's perception of ethical behavior', In die Skriflig 45(2/3), 431-447.

Van der Watt, J.G., 2011, "Thou shalt ... do the will of God": Does the New Testament have anything to say for today? Radboud University Nijmegen, Nijmegen.

Van der Watt, J.G., 2012, 'Ethics of/and the opponents of Jesus in John's Gospel', in J.G. van der Watt \& R. Zimmermann (eds.), Rethinking the ethics of John, pp. 175-191, Mohr Siebeck, Tübingen.

Van der Watt, J.G. \& Kok, J., 2008, 'Die reaksie van Jesus en sy dissipels op geweld in die Evangelie van Johannes', Hervormde Teologiese Studies 64(4), 1813-1835.

Van der Watt, J.G. \& Kok, J., 2008, 'Geweld in die Evangelie van liefde: Die perspektief van die Evangelie van Johannes op geweld teen Jesus en sy dissipels', Hervormde Teologiese Studies 64(4), 1793-1812.

Van der Watt, J.G. \& Kok, J., 2012, 'Violence in a Gospel of love', in P.G.R. de Villiers \& J.W. van Henten (eds.), Coping with violence in the New Testament, pp. 151-183, Brill, Leiden.

Van Zyl, C. \& Nortje-Meyer, S.J., 2007, 'Footwashing as a family event in John 13:1-20', Ekklesiastikos Pharos 89, 341-351. 
Verster, P., 2009, ‘Die liefde van God as aanknopingspunt vir 'n gesprek met Moslems: Die rol van Joh 3:16', Acta Theologica 29(2), 151-168.

\section{Publications focusing on mission in John}

African Christianity is the result of missionary activities. Thus it is no wonder that the topic of mission remained of importance, also to Johannine scholars. The best-known work in this field is that of Okure. More recently mission was redefined with the aid of Johannine material as the movement of the Christianity towards those people who left the church (missional church movement).

Fansaka Biniama, B., 2004, Les missions des individus johanniques: Le casde Marie de Magdala en Jn 20, Peter Lang, Frankfurt am M.

Kok, J., 2010, 'As the Father has sent me, I send you: Towards a missional-incarnational ethos in John $4^{\prime}$, in R. Zimmermann \& J.G. van der Watt (eds.), Moral language in the New Testament, pp. 168-193, Mohr Siebeck, Tübingen.

Kok, J., 2011, 'The chaos of the cross as fractal of life: The birth of the post resurrection, missional dimension in John', Neotestamentica 45(1), 130-145.

Okure, T., 1988, The Johannine approach to mission: A contextual study of John 4:1-42, Mohr Siebeck, Tübingen.

Okure, T., 1991, 'Witnessing in the Johannine communities: A reflection paper', in W. Amewowo, P. Arowele \& B. Balembo (eds.), Johannine communities, pp. 71-85, Catholic Faculty of Kinshasa, Kinshasa.

Okure, T., 1992, 'The significance today of Jesus' commission of Mary Magdalene', International review of mission 81(2), 177-188.

Okure, T., 1995, 'The mother of Jesus in the New Testament: Implications for women in mission', Journal of Inculturation Theology 3(2), 196-210.

Smit, G., 2011, 'Witness in John 1-4: Towards an emerging, missiological church', Verbum et Ecclesia 32(1), 7 pages online. doi: 10.4102/ve.v32i1.389.

Van der Merwe, D.G., 1998, 'John 17: Jesus assigns his mission to his disciples', Skrif en Kerk 19(1), 115-127.

Van der Merwe, D.G., 2000, 'The protection believers can expect from God in the fulfilment of their mission', Skrif en Kerk 21(1), 135-155.

Van der Merwe, D.G., 2003, 'Jesus appoints his disciples as his agents', Acta Patristica et Byzantina 14, 303-324.

\section{Publications on women in Johannine material}

Africa is blessed with some strong woman theologians who made an impact on Johannine research. No wonder that women issues are one of the stronger points of focus in the Johannine research in Africa as a whole. In discussing woman issues, the women in the Gospel (the Samaritan woman, Mary Magdalene, and the mother of Jesus) are of course major themes for study and discussion.

Cornelius, E., 2008, 'I heard the voice of the Samaritan woman in John 4:1-46', Nederduitse Gereformeerde Teologiese Tydskrif 49(3-4), 69-87.

Dube, M.W., 1992, 'Jesus and the Samaritan woman: A Motswana feminist theological reflection on woman and social transformation', Boleswa Journal of Occasional Theological Papers 1(5), 5-9.

Dube, M.W., 2001, 'John 4:1-42: The five husbands at the well of living waters - The Samaritan woman and African woman', in N.J. Njoroge \& M.W. Dube (eds.), Talitha Cum! Theologies of African woman, pp. 40-65, Cluster, Pietermaritzburg.

Du Rand, J.A., 1988, "n Vrouedissipel uit Samaria? Lesergerigte eksegetiese opmerkings oor die vertelde gesprekke in Johannes $4^{\prime}$, in J.C. Coetzee (red.), Koninkryk, Gees en Woord, Huldigingsbundel vir L. Floor, pp. 1999-217, NG Kerkboekhandel, Pretoria.

Du Rand, J.A., 2000, “"Because of the woman's testimony ...": Reading John 4 from a different angle', SA Baptist Journal of Theology 9, 1-10.

Fansaka Biniama, B., 2004, Les missions des individus johanniques: Le casde Marie de Magdala en Jn 20, Peter Lang, Frankfurt am M.

Manus, C.U., 1987, 'The Samaritan woman (Jn 4:17 ff.): Reflections on female leadership and nation building in Africa', African Journal of Biblical Studies 2(1-2), 52-63.

Mautsa, L.M. \& Janse van Rensburg, F.J., 2010, 'The Samaritan woman in John 4 as Leader', Ekklesiastikos Pharos 92, 1-18.

Mbachu, H., 1996, Cana and calvary revisited in the fourth Gospel narrative: Mario-Christology in context, Hansel-Hohenhausen, Frankfurt am M.

Nortje-Meyer, L., 2009, 'The "mother of Jesus" as analytical category in John's Gospel', Neotestamentica 43(1), 123-143.

Nwaigbo, F., 2006, 'Church in Africa and interreligious dialogue in the third millennium: Jesus and the Samaritian woman as a paradigm', Third Millennium 9(4), 38-57. 
Okure, T., 1992, 'The significance today of Jesus' commission of Mary Magdalene', International Review of Mission 81, 177-188.

Okure, T., 1995, 'The mother of Jesus in the New Testament: Implications for women in mission', Journal of Inculturation Theology 3(2), 196-210.

Omotoye, R., 2006, 'Jesus Christ and the adulterous woman: A case for embracing HIV/AIDS patients in Nigeria', in S.O. Abogunrin \& J.O. Akao (eds.), Biblical view of sex and sexuality from African perspective, pp. 300-308, Nigerian Association of Biblical Studies, Ibadan.

Waweru, H.M., 2008, 'Jesus and ordinary woman in the Gospel of John: An African perspective', Swedish Missional Themes 96(2), 139-160.

\section{Publications related to experience, worship and spirituality in Johannine material}

Concreteness is an important element within the spiritual experience of African spirituality. Since the presence of God within the lives of people should, and is, experienced in a concrete way, the importance of themes like life in abundance is a point of interest. Within a holistic worldview spiritual activities form an important part of reality. Mystical experiences and expression within liturgical frameworks are all important within African Christianity. Again the reflection on these aspects of Johannine theology is underexplored within African Johannine research.

\section{Worship and liturgy}

Akpunnonu, P.D., 1991, 'The celebration of feasts (in John's Gospel)', in W. Amewowo, P. Arowela \& B. Balembo (eds.), Johannine communities, pp. 156-180, Catholic Faculty of Kinshasa, Kinshasa.

Muoneke, M.B., 1991, 'Worship and sacraments in John's Gospel', in W. Amewowo, P. Arowela \& B. Balembo (eds.) Johannine communities, pp. 86-117, Catholic Faculty of Kinshasa, Kinshasa.

Suggit, J., 1993, The sign of life: Studies in the fourth Gospel and the liturgy of the church, Galvin \& Soles, Cape Town.

\section{Spirituality and experience}

Draper, J.A., 1997, 'Temple, tabernacle and mystical experience in John', Neotestamentica 31(2), 263-288.

Umorem, A., 1993, Being born again: An interpretation of Jn. 3:3, in relation to Christian religious experiences, Catholic Theological Association of Nigeria, Lagos.

Van der Merwe, D.G., 2013, 'Early Christian spirituality according to the first epistle of John: The identification of different "lived experiences"', HTS Hervormde Teologiese Studies 69(1), 1-9.

Van der Merwe, D.G., 2014, 'Early Christian spiritualities of sin and forgiveness according to 1 John', HTS Hervormde Teologiese Studies 70(1), 1-11.

Van der Merwe, D.G., 2014, 'Old Testament spirituality in the fourth Gospel', Verbum et Ecclecia 35(1), 1-9.

Van der Watt, J.G., 2012, 'Aspects of spirituality as it is reflected in 1 John', Studies in Spirituality. 22, 89-108. doi: 10.2143/SIS.22.0.2182848.

\section{Abundant life}

Kabongo-Mbaya, P.B., s.a., 'Life in abundance: A biblical reflection on John 10:10', Reformed World 4, 67-77.

Owan, K.J.N., 1996, 'Jesus, justice and John 10:10“ Liberation hermeneutics in the Nigerian context', Nigerian Journal of Theology 10(1), 18-42.

Sindima, H.J., 1990, 'Moyo: Fullness of life - A hermeneutic of the Logos in John's Prologue', African Christian Studies 6(4), $50-62$.

\section{Discipleship and Johannine research}

Although the frequency of publications on Johannine discipleship is relatively low, the spread of the articles (both geographically as well as chronologically) shows that it is a theme that receives constant attention.

Du Rand, J.A., 1988, "n Vrouedissipel uit Samaria? Lesergerigte eksegetiese opmerkings oor die vertelde gesprekke in Johannes 4', in J.C. Coezee (red.), Koninkryk, Gees en Woord, Huldigingsbundel vir L. Floor, pp. 199-217, NG Kerkboekhandel, Pretoria.

Du Rand, J.A., 1990, “"Verstaan julle wat Ek vir julle gedoen het?" (Joh 13:12): Die voetewassing as Johannese hupodeigma', in L. Nortje (red.), 'n Vriend in ons poorte: Feesbundel vir PJ du Plessis', pp. 61-74, Randse Afrikaanse Universiteit, Johannesburg.

Du Rand, J.A., 1991, 'Perspectives on Johannine discipleship according to the farewell discourses', Neotestamentica 25(2), 311-326.

Magagula, S.J., 1964, 'John 8:17: The life of costly discipleship', Ministry 4(3), 125.

Tolmie, D.F., 1995, Farewell and discipleship: John 13:1-19:26 in narratological perspective, Brill, Leiden.

Van der Merwe, D.G., 1996, 'A historical survey and critical evaluation concerning discipleship in the fourth Gospel', Skrif en Kerk 17(2), 427-442. 
Van der Merwe, D.G., 1997, 'Towards a theological understanding of Johannine discipleship', Neotestamentica 31(2), 339-359.

Van der Merwe, D.G., 1998, 'John 17: Jesus assigns his mission to his disciples', Skrif en Kerk 19(1), 115-127.

Van der Merwe, D.G., 2002, 'The character of "unity" expected among the disciples of Jesus according to John 17:20-23', Acta Patristica et Byzantina 13, 222-252.

\section{Leadership in Johannine research}

Leadership remains a major and controversial issue in Africa and as time goes by it grows in importance. Again, relatively little research has been done in this regard. It is interesting that two of the three articles deal with the Samaritan woman as a leader. This is consistent with the important role of woman in Africa. This area of research still offers a lot of challenges for Johannine scholars.

Manus, C.U., 1987, 'The Samaritan woman (Jn 4:17 ff.): Reflections on female leadership and nation building in Africa', African Journal of Biblical Studies 2(1-2), 52-63.

Mautsa, L.M. \& Janse van Rensburg, F.J., 2010, 'The Samaritan woman in John 4 as leader', Ekklesiastikos Pharos 92, 1-18.

Ngele, O.K., 2011, 'Exegesis of John 13:1-17: Implication of Jesus' servant leadership model for the church and Nigerian Society', Nsukka Journal of Religious and Cultural Studies 4(1), 64-86.

\section{Different topics related to Johannine research}

Individual researchers also have individual interests which have resulted in articles that are difficult to classify. The focus usually falls on a verse or pericope, or on a specific topic.

Draper, J.A., 2002, 'What did Isaiah see? Angelic theophany in the tomb in John 20:11-18', Neotestamentica 36(1-2), 63-76.

Draper, J.A., 2003, 'The closed text and the heavenly telephone: The role of the Bricoleur in oral mediation of sacred text in the case of George Khambule and the Gospel of John', in J.A. Draper (ed.), Orality, literacy and colonialism in Southern Africa, pp. 57-89, Brill, Leiden. (Semeia 46).

Du Rand, J.A., 1980, 'Eksegetiese kanttekeninge by Johannes 13', Scriptura 1(1), 43-52.

Du Rand, J.A., 1992, '“Julle sal huil en treur maar die wêreld sal bly wees" - 'n Aforisme in Johannes 16:20', in J.H. Barkhuizen, H.F. Stander \& G.J. Swart (reds.), Hupomena: Feesbundel opgedra aan JP Louw, pp. 54-59, Universiteit van Pretoria, Pretoria.
Du Rand, J.A., 1995, 'Does Ho ochlos refer to the 'am ha'ares in John 7:49?', Ekklesiastikos Pharos 156(19), 32-38.

Du Rand, J.A., 2000, "n Ellips skeppingsgebeure in die evangelieverhaal volgens Johannes', Skrifen Kerk 21(1), 243-259.

Du Rand, J.A., 2000, 'Emfusao in John 20:22: An exegetical venture', Ekklesiastikos Pharos 82, 11-18.

Du Rand, J.A., 2005, 'The creation motif in the fourth Gospel: Perspectives on its narratological function within a Judaïstic background', in G. van Belle, J.G. van der Watt \& P. Maritz (eds.), Theology and Christology in the fourth Gospel, pp. 21-46, Brill, Leiden.

Du Preez, J., 1978, "'Sperma tou Theou" in 1 Joh 3:9", Nederduitse Gereformeerde Teologiese Tydskrif 17(1), 105-106.

Dzurgba, A., 1986, 'John's Gospel: A theological reflection', Orita 18(2), 78-92.

Kinoti, H.W., 1999, 'John 1:1-18: An African perspective', in J.R. Levison \& P. Pope-Levison (eds.), Return to Babel: Global perspectives on the Bible, pp. 145-150, Westminster John Knox, Louisville.

Kok, J., 2012, 'The healing of the blind man in John', Journal of Early Christian History 2(2), 36-62.

Kuzenzama, K.P.M., 1979, 'Jn 5-6 ou Jn 6-5? Une question embarrassante de critique Litteraire', Revue Africaine de Théologie 3(5), 61-69.

Manus, C.U., 1991, 'Jesus and the Jewish authorities in the fourth Gospel', in W. Amewowo, P. Arowele \& B. Balembo (eds.), Johannine communities, pp. 135-155, Catholic Faculty of Kinshasa, Kinshasa.

Manus, C.U., 1992, 'John 6:1-15 and its synoptic parallels: An African approach toward the solution of a Johannine critical problem', Journal of the Interdenominational Theological Centre 19(1-2), 47-71.

Matand Bulembat, J.B., 2007, 'Head-waiter and bridegroom of the wedding at Cana: Structure and meaning of John 2.112', Journal for the Study of the New Testament 30(1), 55-73.

Ndombi, J.-R., 1997, 'Le lange des lieux dans l'évangile de Jean', Hekima Review 17, 53-65.

Nortjé, S.J., 1996, 'Lamb of God (John 1:29): An explanation from ancient Christian art', Neotestamentica 30(1), 141-150.

Seynaeve, J., 1977, 'Les citations scripturaires en Jn. 19, 36-37', Revue Africaine de Théologie 1(1), 67-76.

Seynaeve, J., 1983, 'Le theme de "l'heure" dans le quatrième évangile', Revue Africaine de Théologie 7(13), 29-50. 
Tolmie, D.F., 1996, 'John 21:24-25: A case of failed attestation?', Skrif en Kerk 17(2), 420-426.

Tolmie, D.F., 2008, 'Jesus, Judas and a morsel: Interpreting a gesture in John 13:21-30', in J. Verheyden, G. van Belle \& J.G. van der Watt (eds.), Miracles and imagery in Luke and John: Festschrift Ulrich Busse, pp. 105-124, Peeters, Leuven.

Van der Merwe, D.G., 2000, 'The historical and theological significance of John the Baptist as he is portrayed in John 1', Neotestamentica 33(2), 267-292.

Van der Merwe, D.G., 2002, 'The glory-motif in John 17:1-5: An exercise in biblical semantics', Verbum et Ecclesia 23(1), 226-249.

Van der Merwe, D.G., 2003, 'The exposition of John 17:6-8: An exegetical exercise', Hervormde Teologiese Studies 59(1), 169-190.

Van der Merwe, D.G., 2004, 'The interpretation of the revelatory events in John 17:24-26: An exegetical exercise', Verbum et Ecclesia 25(1), 311-329.

Van der Watt, J.G., 1989, 'The use of aionios in the concept zoe aionios in John's Gospel', Novum Testamentum 31(3), 217-228.

Van der Watt, J.G., 1991, 'Die Woord het vlees geword - 'n Strukturele beskrywing van die teologie van Johannes', in J.H. Roberts, W.S. Vorster, J.N. Vorster \& J.G. van der Watt (eds.), Teologie in konteks, pp. 93-130, Orion, Pretoria.

Van der Watt, J.G., 1991, 'Wie of wat is die deurwagter in Joh 10:3?', Nederduitse Gereformeerde Teologiese Tydskrif 32(3), 387-394.

Van der Watt, J.G., 1996, 'Notas oor "Jode" en "Judaisme" in the Evangelie volgens Johannes', Nederduitse Gereformeerde Teologiese Tydskrif 37(1), 193-207.

Van der Watt, J.G., 2001, 'Glo jy? Johannes 20:28-31 Eksegetiese en homiletiese opmerkings', Nederduitse Gereformeerde Teologiese Tydskrif 42(3-4), 444-452.

Van der Watt, J.G., 2009, 'Knowledge of earthly things? The use of غ̇ंírelo in John 3:12', Neotestamentica 43(2), 289-310.

Van der Watt, J.G., 2011, 'Angels in the Gospel according to John', Journal of Early Christian History 1(1), 185-204.

Van der Watt, J.G., 2011, 'Healing of the royal official's son in Joh 4:46-54', Nederduitse Gereformeerde Teologiese Tydskrif 52(3/4), 576-584.

Zuzan, M., 1983, 'Une discussion sur les "oeuvres": Approche éxègetiques de Jn 6,26-30', Revue Africaine de Théologie 7(4), 165-179.

\section{Methods, grammar, structure and style}

One of the characteristics of New Testament scholarship in South Africa is the strong emphasis on ancient languages, especially Greek. Although the picture is wider than this, the major influence came from Prof. J.P. Louw, professor of Greek, initially at the University of the Orange Free State and later at the University of Pretoria. The methodological reflection on John initially focused on structuralism, including discourse analysis and narratology, then moved to the area of metaphorics and imagery and resulted in a much wider appreciation for different methods applied to the Johannine texts. This interest in method was limited to the South. In my view this could be a fruitful area where Johannine scholars across Africa could join forces in their research, not least because there is considerable expertise on methodology in the South, which could be of value in the hermeneutical quests of understanding and applying the biblical text to concrete African situations, something that has received a great deal of attention in the North.

\section{Narratology}

Du Rand, J.A., 1983, 'Die Evangelie van Johannes as getuigende vertelling', Nederduitse Gereformeerde Teologiese Tydskrif 24, 383-397.

Du Rand, J.A., 1984, 'Die leser in die Evangelie volgens Johannes', Fax Theologica 4(2), 45-63.

Du Rand, J.A., 1985, 'The characterisation of Jesus as depicted in the fourth Gospel', Neotestamentica 19(2), 18-36.

Du Rand, J.A., 1986, 'Plot and point of view in the Gospel of John', in J.H. Petzer \& P.J. Hartin (eds.), A South African perspective on the New Testament, pp. 149-169, Brill, Leiden.

Du Rand, J.A., 1988, 'Die betekenis van Martha se belydenis volgens die vertelling van Johannes 11:27', Fax Theologica $8(2), 30-39$.

Du Rand, J.A., 1988, "n Vrouedissipel uit Samaria? Lesergerigte eksegetiese opmerkings oor die vertelde gesprekke in Johannes $4^{\prime}$, in J.C. Coetzee (red.), Koninkryk, Gees en Woord, Huldigingsbundel vir L. Floor, pp. 199-217, NG Kerkboekhandel, Pretoria.

Du Rand, J.A., 1990, ‘Narratological perspectives in John 13:1-38', HTS Hervormde Teologiese Studies 46(3), 367-389.

Du Rand, J.A., 1991, 'A syntactical and narratological reading of John 10 in coherence with chapter $9^{\prime}$, in J. Beutler \& R.T. Fortna (eds.), The shepherd discourse of John and its context, pp. 94-115, Cambridge University Press, Cambridge. 
Du Rand, J.A., 1992, 'A story and a community: Reading the first farewell discourse (John 13:31-14:31) from narratological and sociological perspectives', Neotestamentica 26(1), 31-45.

Du Rand, J.A., 2005, 'The creation motif in the fourth Gospel: Perspectives on its narratological function within a Judaïstic background', in G. van Belle, J.G. van der Watt \& P. Maritz (eds.), Theology and Christology in the fourth Gospel, pp. 21-46, Brill, Leiden.

Du Rand, J.A., 2008, "The Johannine "group" and "grid": Reading John 13:31-14:31 from narratological and sociological perspectives', in J. Verheyden, G. van Belle \& J.G. van der Watt (eds.), Miracles and imagery in Luke and John, pp. 125-139, Peeters, Leuven.

Hunt, S.A., Tolmie, D.F. and Zimmermann, R. (eds.), 2013, Character studies in the fourth Gospel, Mohr Siebeck, Tübingen.

Lemmer, R., 1991, 'A possible understanding by the implicit reader, of some of the "coming-going-being sent" pronouncements in the Johannine farewell discourses', Neotestamentica 25(2), 289-310.

Tolmie, D.F., 1991, 'The function of focalisation in John 13-17', Neotestamentica 25(2), 273-288.

Tolmie, D.F., 1992, Jesus' farewell to the disciples: John 13:117:26 in narratological perspective, Brill, Leiden.

Tolmie, D.F., 1993, 'A discourse analysis of John 15:1-17', Ekklesiastikos Pharos 75(1), 54-79.

Tolmie, D.F., 1993, 'A discourse analysis of John 17:1-26, Neotestamentica 27(2), 403-418.

Tolmie, D.F., 1995, Farewell and discipleship: John 13:1-19:26 in narratological perspective, Brill, Leiden.

Tolmie, D.F., 1998, 'The characterization of God in the fourth Gospel', Journal for the Study of the New Testament 69, 57-75.

Tolmie, D.F., 2006, 'The (not so) good shepherd: The use of shepherd imagery in the characterisation of Peter in the fourth Gospel', in J. Frey, J.G. van der Watt \& R. Zimmermann (eds.), Imagery in the Gospel of John: Terms, forms, themes and theology of figurative language, pp. 353-367, Mohr Siebeck, Tübingen.

Van der Watt, J.G., 2013, 'The angels: Maarking the divine presence', in S.A. Hunt, D.F. Tolmie \& R. Zimmermann, Character studies in the fourth Gospel, pp. 658-662, Mohr Siebeck, Tübingen.

\section{Structuralism}

Du Rand, J.A., 1980, ‘Die ontsluiting van die struktuur van 3 Johannes met die oog op verdere eksegese', Skrif en Kerk 1(1), 33-47.
Du Rand, J.A., 1982, 'A discourse analysis of 1 John', Neotestamentica 13, 1-46.

Du Rand, J.A., 1982, 'The structure and message of 2 John', Neotestamentica 13, 108-138.

Du Rand, J.A., 1982, 'The structure of 3 John', Neotestamentica 13, 129-142.

Matand Bulembat, J.B., 2007, 'Head-waiter and bridegroom of the wedding at Cana: Structure and meaning of John 2.1-12', Journal for the Study of the New Testament 30(1), $55-73$.

Van der Watt, J.G., 1987, 'Die strukturele komposisie van die proloog van Johannes heroorweeg', Skrif en Kerk 8(1), 68-84.

Van der Watt, J.G., 1996, 'The composition of the prologue of John's Gospel: The historical Jesus introducing divine grace', Westminster Theological Journal 57(2), 311-332.

Wong, C.H., 2006, 'The structure of John 17', Verbum et Ecclesia 27(1), 374-392.

\section{Metaphorics, symbolism and imagery}

Joubert, J., 2007, 'Johannine metaphors/symbols linked to the Paraclete-Spirit and its theological implications', Acta Theologica 27(1), 83-104.

Tolmie, D.F., 2006, 'The (not so) good shepherd: The use of shepherd imagery in the characterisation of Peter in the fourth Gospel', in J. Frey, J.G. van der Watt \& R. Zimmermann (eds.), Imagery in the Gospel of John: Terms, forms, themes and theology of figurative language, pp. 353-367, Mohr Siebeck, Tübingen.

Mburu, E.W., 2010, Qumran and the origins of Johannine language and symbolism, Clark, London.

Van den Heever, G., 1992, 'Theological metaphorics and the metaphors of John's Gospel', Neotestamentica 26(1), 89-100.

Van der Watt, J.G., 1992, 'Interpreting imagery in John's Gospel: John 10 and 15 as case studies', in J.H. Barkhuizen, H.F. Stander \& G.J. Swart (eds.), Hupomnema: Feesbundel opgedra aan Prof J P Louw, pp. 272-282, University of Pretoria, Pretoria.

Van der Watt, J.G., 1995, 'Metaphorics in John 15', Biblische Zeitschrift 38(1), 67-80.

Van der Watt, J.G., 1998, 'The dynamics of metaphor in 'John's Gospel', Studien zum Neuen Testament und seiner Umwelt 23, 29-78.

Van der Watt, J.G., 1998, 'Simbolisme in die Evangelie volgens Johannes', Skrif en Kerk 19(2), 392-403. 
Van der Watt, J.G., 1999, 'Die gebruik van metafore in Psalm 80 (79-LXX) in vergelyking met Johannes 15:1-8', Skrif enKerk 20(2), 445-464.

Van der Watt, J.G., 2000, Family of the King: Dynamics of metaphor in the Gospel according to John, Brill, Leiden.

Van der Watt, J.G., 2007, 'I am the bread of life: Imagery in John 6:32-51', Acta Theologica 2, 186-204.

Van der Watt, J.G., 2007, 'The Father shows the Son everything: The imagery of education in John 5,19-23', Acta Patristica et Byzantina 18, 263-276.

Van der Watt, J.G. \& Voges, L., 2000, 'Metaforiese elemente in die forensiese taal in die Evangelie volgens Johannes', Skrif en Kerk 21(2), 387-405.

\section{Style and style related issues}

Botha, J.E., 1991, Jesus and the Samaritan woman. A speech act reading of John 4:1-42, Brill, Leiden.

Botha, J.E., 1991, 'The case of Johannine irony reopened', Neotestamentica 25(2), 209-232.

Du Rand, J.A., 1996, 'Repititions and variations - Experiencing the power of the Gospel of John as literary symphony', Neotestamentica 30(1), 145-156.

Du Rand, J.A., 1998, 'Reading the fourth Gospel like a literary symphony', in F.F. Segovia (ed.), What is John? Literary and social readings of the fourth Gospel, pp. 5-18, Scholars, Atlanta.

Van der Watt, J.G., 2008, 'Johannine style: Some initial remarks on the functional use of repetition in the Gospel according to John', In die Skriflig 42(1), 75-100.

Van der Watt, J.G., 2009, 'Repetition and functionality in the Gospel according to John: Some initial remarks', in G. van Belle \& P. Maritz (eds.), Repetition and variation in the Gospel according to John, pp. 87-108, Peeters, Leuven.

Van der Watt, J.G., 2012, 'Mag deur taal in 1 Johannes', HTS Hervormde Teologiese Studies 68(1), Online art. \#1196, 8 pages. http:/ /dx.doi.org/10.4102/ hts.v68i1.1196.

Van der Watt, J.G. \& Caragounis, C., 2009, 'The grammar of John 1:1', Filologia Neotestamentaria 22, 1-52.

\section{Other methodological approaches}

Domeris, W.A., 1983, 'The Johannine drama', Journal of Theology for Southern Africa 42, 29-35.

Du Rand, J.A., 2006, 'Bringing the reader into exegetical play, applied to the Gospel of John', in J.A. du Rand (ed.), More than one way of reading the Bible, vol. 2, pp. 51-142, University of Johannesburg, Johannesburg.

Nicol, W., 1972, The semeia in the fourth Gospel: Tradition and redaction, Brill, Leiden.

Saayman, C.Z., 1995, 'The textual strategy in John 3:12-14: Preliminary observations', Neotestamentica 29(1), 27-48.

Van der Watt, J.G., 2004, 'Double entendre in the Gospel according to John', in G. van Belle, J.G. van der Watt \& P. Maritz (eds.), Christology and theology in the Gospel of John, pp. 463-481, Peters, Leuven.

\section{Johannine literature read within a social or anthropological matrix}

Inter alia, due to strong contacts between the Context Group and especially (nearly exclusively) South African New Testament scholars, the text of John is also interpreted within social and anthropological frameworks. These insights are used to explain the social language as well as social phenomena within the Johannine texts.

Domeris, W.R., 1991, 'The farewell discourse: An anthropological perspective', Neotestamentica 25(2), 233-272.

Du Rand, J.A., 1992, 'A story and a community: Reading the first farewell discourse (John 13:31-14:31) from narratological and sociological perspectives', Neotestamentica 26(1), 31-45.

Du Rand, J.A., 2008, "The Johannine "group" and "grid": Reading John 13:31-14:31 from narratological and sociological perspectives', in J. Verheyden, G. van Belle \& J.G. van der Watt (eds.), Miracles and imagery in Luke and John, pp. 125-139, Peeters, Leuven.

Kok, J., 2009, 'Die opstanding van Jesus as kulminerende genesingshandeling in Johannes', Verbum et Ecclesia 30(1), 112-147.

Kok, J., 2012, 'The healing of the blind man in John', Journal of Early Christian History 2(2), 36-62.

Moruthane, S.W. \& Nortje-Meyer, L., 2008, 'Family imagery in John', Ekklesiastikos Pharos 90, 81-97.

Snodderly, B. \& Van der Merwe, D.G., 2007, 'Status regeneration in first John: Social scientific and literary perspectives', Acta Patristica et Byzantina 18, 179-213.

Van den Heever, G., 1999, 'Finding data in unexpected places: Towards a socio-rhetorical reading of John's Gospel', Neotestamentica 33(2), 343-364.

Van der Merwe, D.G., 2002, 'The glory-motif in John 17:1-5: An exercise in biblical Semantics', Verbum et Ecclesia 23(1), 226-249. 
Van der Watt, J.G., 2000, Family of the King: Dynamics of metaphor in the Gospel according to John, Brill, Leiden.

Van der Watt, J.G., 2001, 'Fisiese families en aardse families in die Evangelie volgens Johannes', Verbum et Ecclesia 22(1), 158-177.

Van Zyl, C. \& Nortje-Meyer, S.J., 2007, 'Footwashing as a family event in John 13:1-20', Ekklesiastikos Pharos 89, 341-351.

\section{Publications consciously applying Johannine exegetical material to African situations}

What is evident from the articles listed here is the strong conviction within African scholarship that the Bible is important, and should therefore address the respective situations not only of academic readers but also of the ordinary grass roots Christians. How that should be done is, of course, a matter of much debate. Most articles offer some attempt to apply to or interpret the exegetical material for the (their) current African situation. This is usually evident from the titles of these articles.

Bidzoga, G.R., 2006, 'Jesus, the way to the Father in John 14:1-14: A link with the African situation today', Hekima Review 35, 33-45.

Dube, M.W., 1992, 'Jesus and the Samaritan woman: A Motswana feminist theological reflection on woman and social transformation', Boleswa Journal of Occasional Theological Papers 1(5), 5-9.

Dube, M.W., 1996, ‘Reading for decolonialization (John 4:1-42)', Semeia 75, 37-59.

Dube, M.W., 1996, Saviour of the world but not of this world: A post-colonial reading of spatial construction in John, Scholars, Atlanta.

Dube, M.W., 2000, 'Batswaka: Which traveller are you (John 1:1-18)?', in G.O. West \& M.W. Dube (eds.), The Bible in Africa: Transactions, trajectories and trends, pp. 150-162, Brill, Leiden.

Dube, M.W., 2001, 'John 4:1-42: The five husbands at the well of living waters - The Samaritan woman and African woman', in N.J. Njoroge \& M.W. Dube (eds.), Talitha Cum! Theologies of African woman, pp. 40-65, Cluster, Pietermaritzburg.

Dube, M.W., 2002, 'Reading for decolonialization (John 4.1-42)', in M.W. Dube \& J.L. Staley (eds.), John and Postcolonialism: Travel, space and power, pp. 51-755, Sheffield Academic Press, Sheffield.

Du Rand, J.A., 2002, ‘Die Johannese Logos kom opnuut tuis in Afrika', Verbum et Ecclesia 23(1), 80-91.
Du Rand, J.A., 2002, 'The Johannine Jesus in Africa?', in F. Segovia, A. Culpepper \& J. Painter (eds.), World, theology and community in John: Festschrift R Kysar, pp. 211-228, Fortress, Philadelphia.

Folarin, G.O., 2001, The Gospel of John in African perspective, His love Publishers, Ilorin.

Folarin, G.O., 2002, 'Functional Christology in the fourth Gospel: Implications for African Christianity', African Journal of Biblical Studies 18(2), 22-38.

Kang, J., 2003, 'The story of Lazarus (John 11:1-44): Reading from the Malawian context', Malawi Journal of Biblical Studies $1,37-48$.

Kgalemang, M., 2004, 'John 9: Deconstructing the HIV / AIDS stigma', in M.W. Dube \& M.R.A. Kanyoro (eds.), Grant me justice! HIV/AIDS \& gender readings of the Bible, pp. 141-168, Cluster, Pietermaritzburg.

Kinoti, H.W., 1999, 'John 1:1-18: An African perspective', in J.R. Levison \& P. Pope-Levison (eds.), Return to Babel: Global perspectives on the Bible, pp. 145-150, Westminster John Knox, Louisville.

Lombard, H.A., 1998, ‘Orthodoxy and other-worldliness of the church: Johannine perspectives on Christianity in a new South Africa', Neotestamentica 32(2), 497-508.

Manus, C.U., 1987, 'The Samaritan woman (Jn 4:17 ff.): Reflections on female leadership and nation building in Africa', African Journal of Biblical Studies 2(1-2), 52-63.

Manus, C.U., 1992, 'John 6:1-15 and its synoptic parallels: An African approach toward the solution of a Johannine critical problem', Journal of the Interdenominational Theological Centre 19(1-2), 47-71.

Manus, C.U., 2002, 'Reconstructing Christology for Africa of the 21st century: A re-reading of Mark 11:15-19 and parallels: Matt. 21:12-17; Lk. 19:45-48; John 2:13-22', African Journal of Biblical Studies 18(2), 1-21.

Ndayango, A.C.C., 2001, Wunder, Glaube, und Leben bei Johannes: Eine exegetisch-hermeneutische Studie am Beispiel von Joh 3 im Hinblick auf die Inkulturationsaufgabe, Norbert, Bonn.

Ngele, O.K., 2011, 'Exegesis of John 13:1-17: Implication of Jesus' servant leadership model for the church and Nigerian society', Nsukka Journal of Religious and Cultural Studies 4(1), 64-86.

Nwaigbo, F., 2006, 'Church in Africa and interreligious dialogue in the third millennium: Jesus and the Samaritian woman as a paradigm', Third Millennium 9(4), 38-57.

Okure, T., 1993, “"AFES AYTHN” (Jn 12:7): The challenge of the anointing at Bethany (Jn 12:1-8 and parallels) for the contemporary church', in S. Sempore (ed.), Universalisme 
et Mission dans la Bible, pp. 137-146, Katholische Jungschar Oesterreiches et BICAM, Nairobi.

Omotoye, R., 2006, 'Jesus Christ and the adulterous woman: A case for embracing HIV/AIDS patients in Nigeria', in S.O. Abogunrin \& J.O. Akao (eds.), Biblical view of sex and sexuality from African perspective, pp. 300-308, Nigerian Association of Biblical Studies, Ibadan.

Owan, K.J.N., 1996, 'Jesus, justice and John 10:10: Liberation hermeneutics in the Nigerian context', Nigerian Journal of Theology 10(1), 18-42.

Sindima, H.J., 1990, 'Moyo: Fullness of life - A hermeneutic of the Logos in John's prologue', African Christian Studies 6(4), $50-62$.

Tshehla, S.T., 2003, 'Colenso, John 1:1-18 and the politics of insider- and outsider-translating', in J.A. Draper (ed.), The eye of the storm: Bishop John William Colenso and the crisis of biblical interpretation, pp. 29-41, Clark, London.

Van der Watt, J.G., 1998, 'My reading of 1 John in Africa', in I. Kitzberger (ed.), Personal voices in New Testament scholarship, pp. 142-155, Routledge, London.

Waweru, H.M., 2008, 'Jesus and ordinary woman in the Gospel of John: An African Perspective', Swedish Missional Themes 96(2), 139-160.

\section{John and interreligious discussions}

Reflection on the role of Johannine literature within the current interreligious debates (predominantly between African traditional religion, Christianity and Islam) is onesided. When emphasising inculturation the relationship between African traditional religions and Christianity should be noted. Little is however done on the area of the relationship between Christianity and Islam. This issue will become more of a challenge in Africa in the future, especially in the light of clear developments in this direction within international debates. John, with its strong emphasis on Christology, emphasising Jesus as the true way to life (John 14:6), will offer its own challenges based on its exclusive claims about Christ.

Nwaigbo, F., 2006, 'Church in Africa and interreligious dialogue in the third millennium: Jesus and the Samaritian woman as a paradigm', Third Millennium 9(4), 38-57.

Verster, P., 2009, 'Die liefde van God as aanknopingspunt vir 'n gesprek met Moslems: Die rol van Joh 3:16', Acta Theologica 29(2), 151-168.

\section{John and the other gospels}

Although the relation between John and the other Gospels is one of the major points of discussion in traditional Johannine research on historical critical issues, this is not an area of research that was or is of interest to African Johannine scholars. Attention is nevertheless given to this problem in some of the introductions.

Du Rand, J.A., 1991, Johannnine perspectives, part 1: Introduction to the Johannine writings, Orion, Midrand.

Manus, C.U., 1992, 'John 6:1-15 and its synoptic parallels: An African approach toward the solution of a Johannine critical problem', Journal of the International Theological Centre 19(1-2), $47-71$.

Schaeffler, E., 2006, 'Jesus' non-violence at his arrest: The synoptics and John's Gospel compared', Acta Patristica et Byzantina 17, 312-326.

Van der Watt, J.G., 2007, 'Der Meisterschüler Gottes Joh 5,1923 (vgl. Q10,22; Mat 11,27; Luk 10,27)', in R. Zimmermann (ed.), Gleichnis-Kompendium des Neuen Testaments, pp. 745754, Mohr Siebeck, Tübingen.

Van der Watt, J.G., 2007, Introduction to the Gospel and letters of John, Clark, London.

\section{Commentaries and introductory material related to the Johannine literature}

Africans have written several commentaries on John, but none of these can be called a standard or major commentary. There was also limited interest in introductory questions, and both the introductions to John by Du Rand and Van der Watt were and are prescribed internationally. The African Bible Commentary should also be noted, although the project largely excluded Johannine scholars from South Africa.

Du Rand, J.A., 1989, 'Die Evangelie volgens Johannes', in Verklarende Bybel, pp. 110-150, NG Kerk-Uitgewers, Kaapstad.

Du Rand, J.A., 1991, 'Inleiding tot die Johannesevangelie', in A.B. du Toit (red.), Handleiding by die Nuwe Testament, deel 6, pp. 1-36, NG Kerkboekhandel, Pretoria.

Du Rand, J.A., 1991, Johannnine perspectives, part 1: Introduction to the Johannine writings, Orion, Midrand.

Du Rand, J.A., 1994, 'The Gospel according to John, and Revelation', in A.B. du Toit (ed.), Guide to the New Testament, pp. 1-29, 227-263, Lux Verbi, Wellington.

Magezi, V. \& Manzanga, P., 2010, 'A study to establish the most plausible background to the forth Gospel (John)', HTS Hervormde Teologiese Studies 66(1), 7 pages. doi: 10.4102/hts. v68|1.1008.

Ngewa, S.M., 2006, '1+2+3 John', in T. Adeyemo (ed.), Africa Bible commentary, pp. 1529-1538, Zondervan, Grand Rapids. 
Ngewa, S.M., 2006, 'John', in T. Adeyemo (ed.), Africa Bible commentary, pp. 1251-1296, Zondervan, Grand Rapids.

Ngewa, S.M., 2007, The Gospel of John: A commentary for pastors, teachers and preachers, Evangel, Nairobi.

Okure, T., 1998, 'John', in W.R. Farmer (ed.), The International Bible Commentary, pp.1438-1501, Liturgical Press, Collegeville.

Tolmie, D.F., 1995, 'Die presbiter Johannes as outeur van die Johannesevangelie en -briewe?', Nederduitse Gereformeerde Teologiese Tydskrif 35(3-4), 481-492.

Van Aarde, A.G., 1985, 'Die outeurskapsvraag van die Johannesevangelie met die oog op interpretasie of resepsie', Skrif $\mathcal{E}$ Kerk 6, 45-62.

Van Aarde, A.G., 2011, 'Bultmann, R: Sy mees invloedryke bydrae in die 20ste eeu - "Urchristentum", "Jesus", "Johannes"-kommentaar?', HTS Hervormde Teologiese Studies 67(3), 1-7.

Van der Watt, J.G., 2007, Introduction to the Gospel and letters of John, Clark, London.

Van der Watt, J.G., 2009, 'Evangelie volgens Johannes', in W. Vosloo \& F. Janse van Rensburg (red.), Bybellenium: Eenvolume kommentaar, pp. 1314-1370, Christelike Uitgewersmaatskappy, Vereeniging.

Van der Watt, J.G., 2011, '1,2,3 Johannes: 'n Oorsig oor die huidige stand van navorsing rakende inleidingsvraagstukke', Hervormde Teologiese Studies 67(1), Online art \#867, 7 pages. doi: 10.4102/hts.v67i1.867.

Van der Watt, J.G., 2011, '1,2,3 John', in M.D. Coogan (ed.), The Oxford Encyclopedia of the Books of the Bible, vol. 1, pp. 472-477, Oxford University Publishers, Oxford.

\section{Publications related to the letters of John}

Although there are a number of publications on the letters of John, the majority were written by Du Rand and Van der Watt, both from South Africa. It cannot really be claimed that the letters are a topic of major interest in Africa. Johannine scholars in Africa should be encouraged to study these short but powerful letters in more detail. Since Christology and ethics, and their interrelatedness, are focus points in the letters, the content of the letters is especially relevant to African reflections on inculturation.

De Villiers, P.G.R., 2014, 'Union with the transcendent God in Philo and John's Gospel', HTS Hervormde Teologiese Studies $70(1), 1-8$.

Du Preez, J., 1978, “'Sperma tou Theou" in 1 Joh 3:9', Nederduitse Gereformeerde Teologiese Tydskrif 17(1), 105-106.
Du Rand, J.A., 1980, 'Die ontsluiting van die struktuur van 3 Johannes met die oog op verdere eksegese', Skrif en Kerk 1(1), 33-47.

Du Rand, J.A., 1980, “'In waarheid en liefde ...": 'n Metodologiese sleutel tot die verstaan van die tweede Johannesbrief', Humanitas 5(4), 317-326.

Du Rand, J.A., 1982, 'A discourse analysis of 1 John', Neotestamentica 13, 1-46.

Du Rand, J.A., 1982, Entole in die Johannesevangelie en -briewe, Nuwe Testamentiese Werkgemeenskap in Suid-Afrika, Pretoria.

Du Rand, J.A., 1982, 'The structure and message of 2 John', Neotestamentica 13, 108-138.

Du Rand, J.A., 1982, 'The structure of 3 John', Neotestamentica 13, 129-142.

Du Rand, J.A., 1987, 'Teologiese interpretasies in die leerstellige konfliksituasies volgens die Johannesbriewe', Nederduitse Gereformeerde Teologiese Tydskrif 28(3), 142-152.

Du Rand, J.A., 1989, ‘Johanneïse identifikasie: Etiese momente in die Johannesbriewe', Nederduitse Gereformeerde Teologiese Tydskrif 30, 29-47.

Du Toit, A.B., 1990, 'Sondebelydenis volgens 1 Johannes', Nederduitse Gereformeerde Teologiese Tydskrif 31(4), 520-525.

Kotze, P.P.A., 1979, 'The meaning of 1 John 3:9 with reference to 1 John $1: 8$ and 10', Neotestamentica $13,68-83$.

Ngewa, S.M., 2006, '1+2+3 John', in T. Adeyemo (ed.), Africa Bible commentary, pp. 1529-1538, Zondervan, Grand Rapids.

Snodderly, B. \& Van der Merwe, D.G., 2007, 'Status regeneration in first John: Social scientific and literary perspectives', Acta Patristica et Byzantina 18, 179-213.

Umoh, C., 2005, 'Authority, crisis and conflict in the Johannine community: An inculturation hermeneutic of 1 John', Journal of Inculturation Theology 7(1), 15-30.

Van der Merwe, D.G., 2008, 'The past and future time in the present in 1 John', Acta Patristica et Byzantina 19, 290-328.

Van der Merwe, D.G., 2013, 'Early Christian spirituality according to the first epistle of John: The identification of different "lived experiences"', HTS Hervormde Teologiese Studies 69(1), 1-9.

Van der Merwe, D.G., 2014, 'Early Christian spiritualities of $\sin$ and forgiveness according to 1 John', HTS Hervormde Teologiese Studies 70(1), 1-11. 
Van der Watt, J.G., 1988, 'Broederliefde in 1 Johannes', in J.C. Breytenbach (red.), Kerk en konteks, pp. 65-76, NG KerkUitgewers, Pretoria.

Van der Watt, J.G., 1993, 'Jesus, God of Mens!? 1 Joh 1:1-4 eksegeties oorweeg', Nederduitse Gereformeerde Teologiese Tydskrif 34(3), 275-292.

Van der Watt, J.G., 1998, 'My reading of 1 John in Africa', in I. Kitzberger (ed.), Personal voices in New Testament scholarship, pp. 142-155, Routledge, London.

Van der Watt, J.G., 1999, 'Ethics in 1 John: A literary and socioscientific perspective', Catholic Biblical Quarterly 61(4), 491-511.

Van der Watt, J.G., 2000, "“The Spirit gives life": Reading 1 John in African context', Protokolle zur Bibel 9(1), 1-22.

Van der Watt, J.G., 2004, 'Hoe akkuraat kan 'n Bybelvertaling wees? Geboorte (gennaō) in 1 Johannes 5:1-4 as voorbeeld', Hervormde Teologiese Tydskrif 60(3), 1-22.

Van der Watt, J.G., 2011, '1,2,3 Johannes: 'n Oorsig oor die huidige stand van navorsing rakende inleidingsvraagstukke', Hervormde Teologiese Studies 67(1), Online art \#867, 7 pages. doi: $10.4102 /$ hts.v67i1.867.
Van der Watt, J.G., 2011, '1,2,3 John', in M.D. Coogan (ed.), The Oxford Encyclopedia of the books of the Bible, vol. 1, pp. 472-477, Oxford University Publishers, Oxford.

Van der Watt, J.G., 2012, 'Aspects of spirituality as it is reflected in 1 John', Studies in Spirituality 22, 89-108, doi: 10.2143/SIS.22.0.2182848.

Wendland, E., 2007, 'The rhetoric of reassurance in first John: "Dear children" versus the "antichrist"', Neotestamentica 41(1), 173-219.

\section{Concluding remarks}

This survey led to several important insights of which only three are going to be mentioned here. Firstly, certain areas of research that need more attention were identified, especially in the light of what African Christianity appears to need. These include the areas of pneumatology, ecclesiology, and even interreligious discussions. Secondly, the 'distances' (not only geographically but also otherwise) should be overcome so that Africa can pool its Johannine expertise in order to strengthen efforts to develop a true African approach to the Johannine Scriptures. Thirdly, in spite of several monographs, African Johannine research is not well represented when it comes to longer detailed studies in the form of books. This need should also be addressed. 